\title{
The Business Competitiveness of Thailand in the ASEAN Region
}

\author{
Abdullah Al-Swidi (Corresponding author) \\ Othman Yeop Abdullah Graduate School of Business \\ University Utara Malaysia \\ Tel: 60-124-662-754 Email: swidi@uum.edu.my \\ Arfan Shahzad \\ Othman Yeop Abdullah Graduate School of Business \\ University Utara Malaysia
}

Received: December 7, 2013 Accepted: December 24, 2013

doi:10.5296/ber.v4i1.4667 URL: http://dx.doi.org/10.5296/ber.v4i1.4667

\begin{abstract}
Thailand is playing a vital role in the ASEAN region as a developing nation. The World Bank also reported that in 2011Thailand had the $17^{\text {th }}$ rank globally in terms of ease of doing business. This present study attempted to investigate the major factors which influence the overall national competitiveness of Thailand. Moreover, due to the considerable improvement of the business environment, Thailand has been an attractive destination for foreign investors, therefore, mobilized by many multinational companies (MNCs) from all over the world. This study sought to analyze the economic environment of the country and to detect what factors influence most Thailand's national competitiveness, thus, to explain how Thailand becomes an attractive destination for global FDI inflows and can contribute to the global prosperity.
\end{abstract}

Keywords: Competitive Advantage, ASEAN, Thailand, Competitive disadvantage, Economic indicators.

\section{Introduction}

The beginning years of the $21^{\text {st }}$ century has witnessed that the Asian region has started growing dramatically and becoming the most attractive spot for international business in the global arena. The national competitiveness is assumed to be the most important factor that indicates the country's ability to create and maintain a compatible environment in which enterprises and 
organizations can compete and survive by achieving a high level of growth and success (Kao et al., 2007). The present study sought to analyze the national advantages and disadvantages which affect creating the strategic competitiveness of Thailand, as a promising nation in the Asian region, when the people's current outlook is to consider Asia as a new engine of sustainable global growth and development.

Kao et al., (2007) tried to measure the national competitiveness of Southeast Asian countries and observed that Singapore, Malaysia, and Thailand have the highest national competitiveness while Myanmar, Cambodia, and Laos are the least competitive countries. The focus of the present study, therefore, tend to examining Thailand's potentials and position in Asia's global race in today's business arena.

Over the new millennium years, Thailand has waded through a remarkable revival program since 1997 crises and achieved one of the highest growth rates in the ASEAN region. Currently, Thailand is intentionally trying to exploit its natural resources, intense labor force, and fertility of the soil and other competitive factors as far as possible to remain at the competitive edge in the rapidly changing world.

\section{Economic Scenario of Thailand}

Investors are usually more interested in perceiving the economic features of the country in global settings. Many economic elements of Thailand are analyzed in this section:

\subsection{Economic Sectors}

In the past, the economy of Thailand was purely based on agricultural activities where the major part of the population was occupationally confined to Agriculture. With the transformation of the economy towards growing Industry-based economy, and then Service-based economy, the contribution of each sector to the total GDP have structurally changed and the occupational composition distribution of the workforce tended to keep changing. In the modern era of IT and communication, the Thai economy has also tended to move towards becoming Knowledge-based economy. Consequently the demand of IT-trained workforce and the distribution of the labor force have a tendency to shift gradually in this direction. Thailand is dynamically expanding in its entire major economic sector in the new millennium years.

To perceive the current scenario, based on the data for the period 2003-2011 the contribution of major economic sectors to the total GDP of Thailand is captured in Table 1.

Table 1. Sectorial Contribution to the GDP of Thailand (2003-2011)

\begin{tabular}{|c|c|c|c|}
\hline Years & Agriculture & Industry & Services \\
\hline 2003 & $10.4 \%$ & $43.6 \%$ & $46 \%$ \\
\hline 2004 & $10.3 \%$ & $43.4 \%$ & $46.3 \%$ \\
\hline 2005 & $10.3 \%$ & $44.0 \%$ & $45.7 \%$ \\
\hline 2006 & $10.7 \%$ & $44.4 \%$ & $44.8 \%$ \\
\hline 2007 & $11.4 \%$ & $43.9 \%$ & $44.7 \%$ \\
\hline 2008 & $11.4 \%$ & $44.5 \%$ & $44.1 \%$ \\
\hline
\end{tabular}




\begin{tabular}{|l|c|c|c|}
\hline 2009 & $9.0 \%$ & $39.0 \%$ & $52.4 \%$ \\
\hline 2010 & $8.6 \%$ & $39.0 \%$ & $52.4 \%$ \\
\hline 2011 & $13.3 \%$ & $34.0 \%$ & $52.7 \%$ \\
\hline
\end{tabular}

Source: Foreign Direct Investment Inflows: UNCTAD; Country Profile, 2012

Figure 1 reflects that the contributions of Agriculture, Industry, and Services to the GDP of Thailand over the period 2003-2011 has remained almost constant and no much difference from year to year can be noticed.

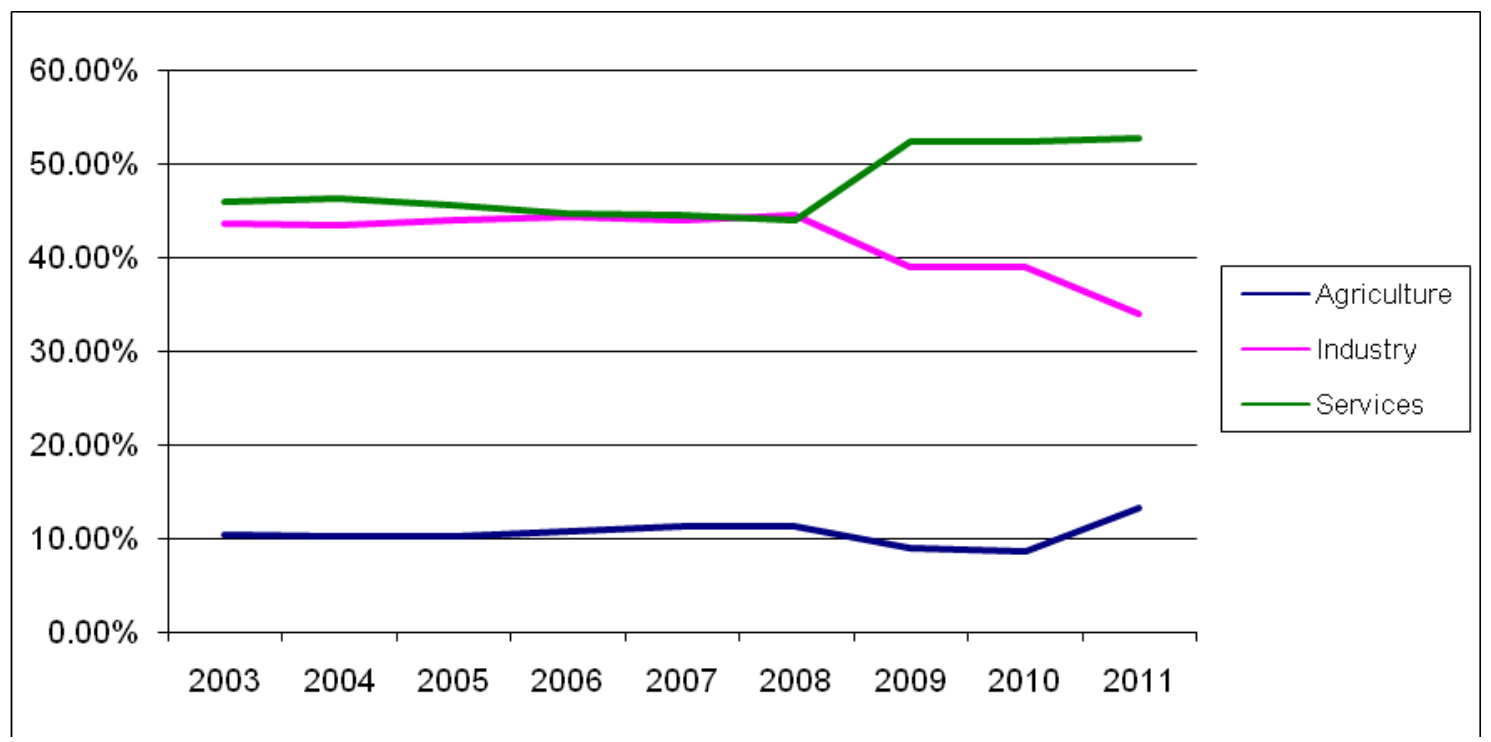

Figure 1. Sectorial contribution to the GDP of Thailand

Source: Foreign Direct Investment Inflows: UNCTAD; Country Profile, 2011

Based on the data of 2007 the following pie chart indicates that industry and service sectors accounts for almost $90 \%$ of the total GDP of the country. This eventually reflects how fast the transformation of the economy of this country has taken place against the agrarian characteristics.

Figure 2. Sectorial contribution to the GDP in Thailand 
Source: Foreign Direct Investment Inflows: UNCTAD; Country Profile, 2011

\subsection{Economic Growth}

It is disheartening to note that since 2003 the economy of Thailand has been experiencing a steady decline of its growth rate. The following Table and Chart depict the trend of growth rate of Thailand economy over the period (2003-2011).

Table 2. Thailand's economic growth rate, 2003-2011

\begin{tabular}{|c|c|c|c|c|c|c|c|c|c|}
\hline Year & 2003 & 2004 & 2005 & 2006 & 2007 & 2008 & 2009 & 2010 & 2011 \\
\hline Growth Rate & $7.1 \%$ & $6.3 \%$ & $4.5 \%$ & $5.1 \%$ & $4.8 \%$ & $2.5 \%$ & $-2.3 \%$ & $7.8 \%$ & $0.1 \%$ \\
\hline
\end{tabular}

Source: Euromonitor International-Statistics, UNCTAD2011.

It follows that Thai economy declined sharply in the year 2005 , to $4.5 \%$, followed by an increase to around $5.1 \%$ in 2006 again and slowly decreased to $4.7 \%$ by 2008 .Imperatively, Thai policy-makers need to have prime consideration to improve the economic growth rate of the country in the future. A set of developmental growth programming is needed.

\subsection{FDI Inflows}

In the new global economic era the foreign direct investment(FDI) is considered to be a major contributor to the economic growth of any country(World Bank,(2005), World Development Report 2005). Furthermore, the emerging economies have been the major attracting spots for the increasing inflow of global FDI(Meyer \& Estrin, 2004). In the South East Asia region, Thailand has been keen on attracting FDI from all over the world to promote its economic development, employment, and technological advancements of the country.

The inflows of FDI serves as an indicator of how healthy is the economy of a country. Indeed, Thailand is one of the developing countries that receive a huge amount of FDI during recent times. The following table shows the inflow of FDI into Thailand and the growth of the ratio of FDI to GDP. The scenario is further portrayed by the visual aids of Figure 3.

Table3. FDI Inflows in Thailand, 2003-2011(Million USD)

\begin{tabular}{|c|c|c|c|}
\hline Years & FDI & GDP & FDI/GDP \\
\hline 2,003 & 5,235 & 142,640 & $3.7 \%$ \\
\hline 2,004 & 5,862 & 161,340 & $3.6 \%$ \\
\hline 2,005 & 8,048 & 176,420 & $4.6 \%$ \\
\hline 2,006 & 9,010 & 206,703 & $4.4 \%$ \\
\hline 2,007 & 9,575 & 245,351 & $3.9 \%$ \\
\hline 2,008 & 8,455 & 276,877 & $3.1 \%$ \\
\hline 2,009 & 4,854 & 263,368 & $1.8 \%$ \\
\hline 2,010 & 9,733 & 318,474 & $3.1 \%$ \\
\hline 2,011 & 9,572 & 345,670 & $2.8 \%$ \\
\hline
\end{tabular}

Source: Euromonitor International-Statistics, UNCTAD 2011 


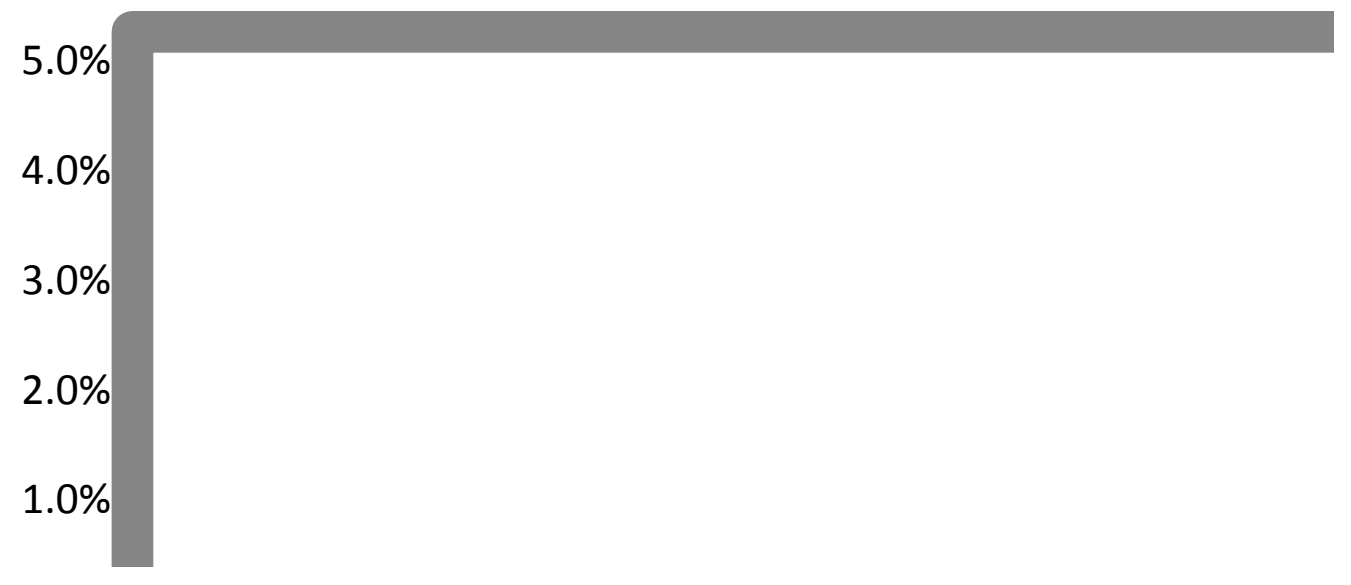

Figure 3. FDI Inflows in Thailand

Source: Euromonitor International-Statistics, UNCTAD 2011

\subsection{Degree of Openness}

The degree of openness is an indicator of the level of global integration of a nation. It is measured in terms of the trade ratio:

$\mathrm{DOO}=((\mathrm{X}+\mathrm{M}) / \mathrm{GDP}) * 100$

Where, $\mathrm{X}$ is the annual export value, $\mathrm{M}$ is the annual import value, and GDP is the Gross Domestic Products.

Thai economy maintained more than $100 \%$ as Trade Ratios or degrees of Openness (DOO) during the period 2003-2011.

Table 4. Thai DOO, 2003-2011

\begin{tabular}{|c|c|}
\hline Years & Degree of Openness \\
\hline 2003 & $109 \%$ \\
\hline 2004 & $118 \%$ \\
\hline 2005 & $129 \%$ \\
\hline 2006 & $126 \%$ \\
\hline 2007 & $120 \%$ \\
\hline 2008 & $132 \%$ \\
\hline 2009 & $102 \%$ \\
\hline 2010 & $112 \%$ \\
\hline 2011 & $124 \%$ \\
\hline
\end{tabular}

Source: Euromonitor International-Statistics, UNCTAD 2011

It follows that these has been a rising trend in the degree of openness of the country. In 2008, the trade ratio is estimated to be around $132 \%$. 


\subsection{Ease of Doing Business}

This indicator is very crucial for attracting FDI, since the foremost factor seen by the investors before deciding about their investment is how easy to start up the business and what incentives offered by the country to attract FDI. Data in Table 5 help in perceiving the ease of doing business in selected ASEAN countries.

Table 5. Ease of Doing Business Indices in Selected ASEAN Countries in 2011

\begin{tabular}{|l|c|c|c|c|c|c|c|c|c|c|c|}
\hline \multicolumn{1}{|c|}{ Economy } & $\begin{array}{c}\text { Ease of } \\
\text { Doing } \\
\text { Business } \\
\text { Rank }\end{array}$ & $\begin{array}{c}\text { Starting } \\
\text { a } \\
\text { Business }\end{array}$ & $\begin{array}{c}\text { Dealing } \\
\text { with } \\
\text { Construction } \\
\text { Permits }\end{array}$ & $\begin{array}{c}\text { Employing } \\
\text { Workers }\end{array}$ & $\begin{array}{c}\text { Registering } \\
\text { Property }\end{array}$ & $\begin{array}{c}\text { Getting } \\
\text { Credit }\end{array}$ & $\begin{array}{c}\text { Protecting } \\
\text { Investors }\end{array}$ & $\begin{array}{c}\text { Paying } \\
\text { Taxes }\end{array}$ & $\begin{array}{c}\text { Trading } \\
\text { Across } \\
\text { Borders }\end{array}$ & $\begin{array}{c}\text { Enforcing } \\
\text { Contracts }\end{array}$ & $\begin{array}{c}\text { Closing a } \\
\text { Business }\end{array}$ \\
\hline Singapore & 1 & 4 & 3 & 5 & 14 & 8 & 2 & 4 & 1 & 12 & 2 \\
\hline United States & 3 & 13 & 17 & 17 & 16 & 4 & 5 & 72 & 20 & 7 & 15 \\
\hline United Kingdom & 7 & 19 & 22 & 60 & 68 & 1 & 10 & 24 & 13 & 21 & 6 \\
\hline Japan & 20 & 107 & 63 & 26 & 58 & 24 & 17 & 120 & 16 & 34 & 1 \\
\hline Thailand & 17 & 78 & 14 & 9 & 28 & 67 & 13 & 100 & 17 & 24 & 51 \\
\hline Malaysia & 18 & 50 & 113 & 59 & 59 & 1 & 4 & 41 & 29 & 31 & 47 \\
\hline Pakistan & 105 & 90 & 104 & 166 & 125 & 67 & 29 & 158 & 75 & 154 & 74 \\
\hline China & 91 & 151 & 179 & 115 & 40 & 67 & 97 & 122 & 60 & 16 & 75 \\
\hline Brunei & 83 & 136 & 83 & 28 & 107 & 126 & 122 & 20 & 35 & 151 & 44 \\
\hline Vietnam & 98 & 103 & 67 & 135 & 47 & 24 & 166 & 151 & 68 & 30 & 142 \\
\hline India & 132 & 166 & 181 & 98 & 97 & 40 & 46 & 147 & 109 & 182 & 128 \\
\hline Indonesia & 129 & 155 & 71 & 161 & 99 & 126 & 46 & 131 & 39 & 156 & 146 \\
\hline Cambodia & 138 & 171 & 149 & 130 & 110 & 98 & 79 & 54 & 120 & 142 & 149 \\
\hline Philippines & 136 & 158 & 102 & 54 & 117 & 126 & 133 & 136 & 51 & 112 & 163 \\
\hline Lao PDR & 165 & 89 & 80 & 138 & 72 & 166 & 182 & 123 & 168 & 110 & 183 \\
\hline
\end{tabular}

Source: Ease of Doing Business 2011

\subsection{Trends of Exports and Imports}

Global economic growth is facilitated by the participating nation's global trade and investment flows. In the case of Thailand, as the total GDP of Thai economy has grown dramatically throughout the period (2003-2008) both exports and imports are growing steadily through the period with almost linear growth. This can be considered as an encouraging factor for both investors in either importing or exporting activities.

Table 6. GDP and Exports and Imports of Thailand, 2003-2011

\begin{tabular}{|c|c|c|c|}
\hline year & GDP & Export & Import \\
\hline 2003 & 142640.1 & $80,323.60$ & $75,824.30$ \\
\hline 2004 & 161339.9 & $96,248.20$ & $94,409.80$ \\
\hline 2005 & 176419.7 & $110,178.00$ & $118,158.00$ \\
\hline 2006 & 206703.2 & $130,803.00$ & $128,723.00$ \\
\hline 2007 & 245350.6 & $153,100.00$ & $140,795.00$ \\
\hline 2008 & 276877.4 & $179,593.70$ & $185,129.40$ \\
\hline 2009 & $263,367.70$ & $150,818.60$ & $118,198.90$ \\
\hline 2010 & $318,473.50$ & $193,655.80$ & $161,896.60$ \\
\hline 2011 & $345,670.30$ & $225,365.90$ & $201,863.90$ \\
\hline
\end{tabular}

Source: Euromonitor International-Statistics, UNCTAD 2011 
Incidentally, Thailand's export partners are US 17\%, Japan 14.2\%, Singapore 7.3\%, China 7.1\%, Hong Kong 5.4\%, and Malaysia 4.8\%, whereas its import partners are Japan 24.1\%, US 9.5\%, China 8\%, Malaysia 6\%, Singapore 4.3\%, and Taiwan 4.2\%.(See, Investment Review: Foreign Investment climate, 2007for further details.)

\subsection{Interest Rate}

In modern economy, interest rate behavior is an important consideration of the currency's economic fundamentals looked upon by the investors. In Thailand, the interest rate for the period (2003-2011) is between 5.5\% and 5.5\% as shown in table 7 .

Table 7. Interest Rate Trend in Thailand, 2003-2011

\begin{tabular}{|c|c|c|c|c|c|}
\hline Year & 2007 & 2008 & 2009 & 2010 & 2011 \\
\hline Interest rate & $3.5 \%$ & $3.0 \%$ & $3.9 \%$ & $2.2 \%$ & $2.6 \%$ \\
\hline
\end{tabular}

Source: Annual Lending Rates: International Monetary Fund (IMF), International Financial Statistics, 2011

It follows that in 2007, interest rate was at the peak level of 3.5\%. This has declined to $2.6 \%$ in 2011. If the declining trend persistsfor the coming years, it would create an encouraging financial sector environment for the investors' point of view.

\subsection{Propensity to Export and Import}

The propensity to export and import are calculated by using the following formulae:

$$
\begin{aligned}
& \text { Propensity to Export }=\left(\frac{\text { Export }_{t}-\text { Export }_{t-1}}{G D P_{t}-G D P_{t-1}}\right) \% ; \\
& \text { Propensity to Import }=\left(\frac{\operatorname{Im} \text { port }_{t}-\operatorname{Im} \text { port }_{t-1}}{G D P_{t}-G D P_{t-1}}\right) \%
\end{aligned}
$$

Using the data of exports and imports of Thailand for the period (2003-2011), export and import propensities are measured and reported in table 8 .

\begin{tabular}{|c|c|c|c|c|c|c|c|c|}
\hline Indicator/Year & 2004 & 2005 & 2006 & 2007 & 2008 & 2009 & 2010 & 2011 \\
\hline GDP & 18699.8 & 15079.8 & 30283.5 & 38647.4 & 31526.8 & 263367.7 & 318473.5 & 345670.3 \\
\hline Export & 15924.6 & 13929.8 & 20625.0 & 22297.0 & 26493.7 & 150818.6 & 193655.8 & 225365.9 \\
\hline Import & 18585.5 & 23748.2 & 10565.0 & 12072.0 & 44334.4 & 118198.9 & 161896.6 & 201863.9 \\
\hline Propensity & \multirow{2}{*}{$85 \%$} & \multirow{2}{*}{$92 \%$} & \multirow{2}{*}{$68 \%$} & \multirow{2}{*}{$58 \%$} & \multirow{2}{*}{$84 \%$} & \multirow{2}{*}{$57 \%$} & \multirow{2}{*}{$61 \%$} & \multirow{2}{*}{$65 \%$} \\
\hline to Export & & & & & & & & \\
\hline Propensity & \multirow{2}{*}{$99 \%$} & \multirow{2}{*}{$157 \%$} & \multirow{2}{*}{$35 \%$} & \multirow{2}{*}{$31 \%$} & \multirow{2}{*}{$141 \%$} & \multirow{2}{*}{$45 \%$} & \multirow{2}{*}{$51 \%$} & \multirow{2}{*}{$58 \%$} \\
\hline to Import & & & & & & & & \\
\hline
\end{tabular}

Table 8. Export and Import Propensities of Thailand, 2004-2011

Source: Euromonitor International-Statistics, UNCTAD 2011 


\section{Macrothink}

Business and Economic Research

ISSN 2162-4860 2014, Vol. 4, No. 1

It appears that Thailand propensity to import is dominant for the period (2004-2008) except for 2006, 2007 where the export propensity was more than that of import propensity.

\subsection{Inflation Rate}

Inflation rate is an important aspect of a country's good economic fundamentals. Theinflation rates for the period of (2003-2011) are shown in the following table:

Table 9. Inflation Rate in Thailand, 2003-2011

\begin{tabular}{|c|c|}
\hline Year & Inflation Rate \\
\hline 2003 & 1.8 \\
\hline 2004 & 2.8 \\
\hline 2005 & 4.5 \\
\hline 2006 & 4.6 \\
\hline 2007 & 2.2 \\
\hline 2008 & 5.5 \\
\hline 2009 & -0.9 \\
\hline 2010 & 3.3 \\
\hline 2011 & 3.8 \\
\hline
\end{tabular}

Source: Annual rates of inflation: Euromonitor International from International Monetary Fund (IMF), International Financial Statistics and World Economic Outlook/UN/national statistics.

The inflation rate has increasing trend over the period even though it shows a sudden fall to around $2.2 \%$ by 2007 .

\subsection{Corruption Index}

Smooth international business conduct is possible in a country where its administration and legal set-up is corruption free. However, corruption in Thailand is one of the major barriers to doing business. Corruption level in Thailand is as much as in Mexico, but less than that of China, India, or Vietnam.(See, Thailand Telecommunications Report Q2 2009).

The corruption indexes of Thailand for the period (2003-2008) are stated in the table10.

Table 10. The Control of Corruption Indexes Thailand, 2002-2011

\begin{tabular}{|c|c|}
\hline Year & Control of Corruption Index \\
\hline 2002 & 47.8 \\
\hline 2003 & 52.7 \\
\hline 2004 & 51.7 \\
\hline 2005 & 52.7 \\
\hline 2006 & 44.4 \\
\hline 2007 & 43.2 \\
\hline 2008 & 42.2 \\
\hline 2009 & 47.8 \\
\hline 2010 & 46.4 \\
\hline 2011 & 44.5 \\
\hline
\end{tabular}

Source: Worldwide Governance Indicators (WGI), 2012 


\section{Thailand's National Competitive Advantages}

Thailand's determinant factors of national competitive advantages have been developed and strengthened over a long period of time. A perception of this is reviewed in the following sections.

\subsection{Population (Human Resources)}

The population in Thailand is nearly 66.8 million as in April 2009 (Thailand National Statistics Office, 2009). Demographically, most of the population is aged between 15-59 years, and the population growth rate has been moderate at $0.7 \%$ in 2007(Country profile, 2008). The country's workforce distribution in different economic sectors reported to be $49 \%$ in agriculture; \%14 in industry; and37 \% in service. (See, "Investment Review: Foreign Investment climate," 2007 for further details). In relative term, among the South-east Asian countries, Thailand has a big number of populations and low cost labor force that has made the country as an attractive business environment in the region. Furthermore, the literacy rate among the population over 6 years is quite high at $91 \%$.

In today's world, the objective of any organization is not confined to only how much the performance of employees or labors (quantity)! But also about how good and innovative their performance (quality)! In modern time, the work operation has become more knowledge-based so the employees can improve the job performance through their ability to generate new ideas and implement them to provide new services and work processes (Jong \& Hartog, 2007). As such, there is a noticeable great attention is being paid by Thailand's public and private organizations towards capitalizing in training and improving qualification of labors and employees to achieve successfully the local and international goals of the organization.

The government of Thailand has planned an effective set of measures for promoting Research and Development (R\&D) in the country. For instance, the Board of Investment (BOI) has granted full incentives for the promotion of $R \& D$ investment instead of labor intensive projects since 2006. It has approved 33 projects with a combined investment of $\$ 133.9$ million (See, Thailand: Country Analysis Report, 2009).

\subsection{Thai Economy's Potential}

The economy of Thailand had grown rapidly for the last forty years, but during the late 1990s it experienced economic problems with a rapid decline in their real estate market, stock market, and a severe decline in the value of their currency, the Thai baht. The economy of Thailand started to recover soon after the crises and many consequent problems were being planned to be solved by the end of 1999. So, looking back to the position of the economy of Thailand 25 years ago, and how the crises hit the whole growing economy, it is impressive to see how fast Thailand's economy is going to resume its growing trend (Thailand Country Profile, 2008).

In economic term one main factor which influences Thailand's competitive advantage is its major natural resources like fluorite, gypsum, lead, lignite, natural gas, rubber, tantalum, tin, tungsten, and renewable resources include fish and timber(Thailand Country Profile, 2007). 


\subsection{Climate}

Climatic natural environment of Thailand contains varieties of different climates for different regions: the Northeast, North, and Central regions have a savannah-type climate, the Central and upper Southern regions have a tropical monsoon climate, and the lower Southern region has a tropical rainforest climate. Of course, these varieties of different climate are providing the country with a solid ground to become an attractive destination for tourists and agriculture-driven investors(Bangkok Companies website,2009).

\subsection{Agriculture and Agro-Industry}

In the agrarian landscape of Thailand, it has very good quality soil which is promising for high productive agricultural activities. Therefore, Thailand is regarded as a destination for those who want to invest in Agricultural enterprises to benefit from its natural resources as productive land, water availability, and cheap labours.

Agriculture and Food-based Industry has grown dramatically and its performance was encouraging for local and global investors. Rice, for example, is the first most important exportable commodity. Its production occupies more than half of all farmland. Rice surplus beyond domestic consumption is exported and represents one-third of the agricultural export value. Fishery exports, both from wild catching and aquaculture, especially shrimp, have been the number one export activity.

The second most important export commodity is the rubber. Therefore, many MNCs which are focusing on these products as their main raw material could find in Thailand their best place to establish their factories or organizations. Over the past few decades, Thailand has successfully utilized innovations in agricultural research and technology to develop a dynamic agricultural sector.

The productivity of farms in Thailand has been increasing comparatively and the quality of corps and food agricultural products have been enhanced. The investment in agricultural research resulted in increasing of yields and land productivity, and this in turn enabled the Thai food and agricultural products to enter in global markets. Nowadays, Thailand is a giant exporter of varieties of foods and agricultural products. After the Asian financial crises and its consequences on Thai economy as a whole, Thai agricultural exports has increased significantly such as: rice, rubber, shrimp, poultry, cassava, and corn. This indicated that the strengths of Thai's economy lies in its agricultural sector. Its expanding growth need to be sustained in the Thai policy agenda.

Globally Thailand is the world's top exporter of rice, canned pineapples and pineapple juice and concentrates, and is among the top ten exporters of seafood, frozen shrimp and frozen chicken, with agricultural exports accounting for roughly $15 \%$ of total exports, and also it produces one third of the global production of rubber (Board of Investment website).

It is heartening to note that Thailand's ninth five-year plan (2002-2006) was the first plan that proposed a framework for the development of food industry to enhance the competitiveness of the country. The objective of this plan was to lead the country to the position of being a major 
world processed food producer and exporter, the tenth plan (2007-2011) shared the same objective as same as the previous plan.

\subsection{Manufacturing and Industry Potential}

To encourage the industry and manufacturing processes, Thailand has developed ten free trade zones. These zones are for exports only, through which raw materials and finished products can move free of duties. These zones are located within industrial estates, and many have customs facilities to speed processing. In addition, there is forward linkage that many factories can establish their warehouse to which their raw materials which will be used for manufacturing the for-export products can be imported duty free.

The Industrial Estate Authority of Thailand (IEAT), which is under the Ministry of Industry as well as the private sector, established many industrial estates. The IEAT operates twelve estates, plus 22 more in conjunction with the private sector in 14 provinces nationwide. Private sector businesses operate over 50 industrial estates, most of which have received promotional incentives from the Board of Investment(See, Thailand Country Conditions Climate for Investment \& Trade( Jan,2008)

\subsubsection{Automobile Industry}

These days, automobile industry has become a king-pin of the Thai industrial progress. Thailand is fast making a name for itself as the 'Detroit of the East'. In the past few years, the auto industry has seen substantial growth, and all indicators suggest that this upward trend will continue, and not just through fast-paced domestic consumption. In early 2005, the Thailand Automotive Institute proposed its ambitious 'Detroit of Asia' development plan to increase revenue from automobiles and auto parts to 1.3 trillion baht by 2010, with a view to make Thailand the ninth largest vehicle manufacturer in the world. The plan is an extensive one aimed at boosting both quality and quantity. The multi-faceted strategy in this context involved a human-resources development programme, the dispatch of highly trained experts to upgrade the technology used in making auto parts, the establishment of research-and-development centers, an IT headquarters to analyze the industry's trends, and an export promotion office(See, "Thailand Industry Forecast December 2005," for further details).

In fact, these days most of the world's major automobile companies have assembly lines and auto parts manufacturing plants in Thailand. All the big brands of the Japanese auto industry Toyota, Isuzu, Nissan, Honda and Mitsubishi - have major investments in the Kingdom. Other bigname investors include BMW and Volvo. The big three auto companies of the United States namely, Ford, Daimler-Chrysler and General Motors have undertaken joint ventures with local Thai companies. Moreover, high-end luxury car makers such as Alfa Romeo and Porsche have established their footholds in the up-and-coming regional capital of the auto industry(Thailand Industry Forecast December 2005).

In Thai economy, thus, auto's production has been expected to continue to grow strongly in 2005-2009 due to the growing level of investment in automobile sector, and due to the rising of domestic and international demand. Thai Automotive Industry Association are expecting high level of investment and the number of output was expected to exceed 1.5 million units a year by 
2009(See, Thailand Industry Forecast December, 2005).

\subsubsection{Industrial Machinery, Electrical and Electronics}

The electronics sector has recorded strong growth in 2003-2006, with an average growth of $25 \%$ a year, before slowing in 2007. Companies which are manufacturing integrated circuits and hard disk drives (HDDs) have gained impressively. Since many global companies were behind the expansion of production of HDD, Thailand has become an increasingly attractive destination for HDD producers. In fact, this expansion is due to the promotional incentives offered by the Board of Investment (BOI), which made HDD production one of its main priorities (Thailand Country Profile, 2007).

Furthermore, the electrical appliances manufacturing sector has been regarded as one of the attracting manufacturing sectors. Some of the essential features which attract greater investment to Thailand is that foreign firms can benefit from low tariff privileges under ASEAN free-trade areas(Thailand Country Profile, 2007).

\subsubsection{Information Technology and Technology Management}

Thai policy-makers are well aware of the need for expanding IT sector, therefore, since 1992, the Thai government started to promote the information technology by appointing different committees to take care of planning and implementing the improvement of this sector. Two major policies are worth mentioning in this regard, the first national policy (IT-2000) covered the period 1996-2000 and focused on the following:

Investment in information technology infrastructure.

Investment in people to make them technological literate.

To spread the informational knowledge to reduce the societal and economic gap.

The second national policy (IT-2010) which covered the period 2001-2010 extended the objectives of the first policy and incorporate 5 other field which are the foundation for modern Thailand such as: e-government; e-industry; e-commerce; e-education; e-society (Winley, Arjpru, \& Wongwuttiwat, 2007). These policies were expected to lead to sustainable development of knowledge-based economy of Thailand.

In their study, Intarakumnerd \& Panthawi (2003), have analyzed the results of the two policies and noticed that there is a remarkable progress in the development of: information infrastructure as could be seen by the increasing number of communication organizations established in Thailand providing fiber optic cable and the number of telephones; Furthermore, the legal acts for online transactions, data privacy, computer crime, and data protection; the computer professional employees in schools, schools networks, and universities' networks. Despite all these, the IT manpower demand in the country is not yet satisfied. The policy-makers have to take suitable measures in this direction.

\subsection{Infrastructures and Transportation}

The government of Thailand has planned to spend around THB1.6tn-1.8tn over the period 
(2008- 2011). The planned projects include Bangkok's mass transit system, as well as public housing, energy, roads, railways, bridges, water management system, and airport development(Thailand Infrastructure Report Q2, 2009). Other aspects of infrastructure are discussed in the following sections:

\subsubsection{Electricity Supply}

The geography of Thailand serves transforming Thailand to become the energy hub in the region. The electrical authorities in Thailand are tirelessly developing the country's electric power system to ensure that its electricity supply remains at the satisfactory level. They are also exerting all its possible efforts that can ensure that the power supply has a secure and reliable infrastructure service to contribute significantly to the betterment of the quality of life and the environment, and drives the country's economic and social growth in the future and to attract FDI to the country. Moreover, Thailand has a stable and dependable electricity generating system that is meant to provide power at reasonable price(For details, see, Thailand Board of Investment (BOI), 2009).

\subsubsection{Water Supply}

Water is the source of life, water management is a crucial factor for survival and growth, the Thai government is working seriously at maintaining Thailand's water at international standards.

The population growth, industrial growth, and the rising incomes have led to an increased demand for water. Water Demand is projected to be growing $20 \%$ a year, but the investment program of the Provincial Waterworks Authority (PWA) has increased supplies about $12 \%$ a year. The PWA has the capacity to serve about $60 \%$ of the 10 million people living in the 220 cities and towns under its jurisdiction with about 1.2 million cubic meters a day(Thailand Board of Investment (BOI) website).

In statistical term, demand for water is about 53 billion cubic meters annually. The water supply is distributed such as: almost $90 \%$ is allocated for agriculture, $6 \%$ for consumption, and the rest for industrial use. Water Demand in the country is estimated at 70 billion cubic meters annually in the next 10 years. The annual rainfall of Thailand is between 1,200 and 2,700 millimetres and there are 25 river basins in Thailand. The amount of average annual runoff is 200 billion cubic meters, but only 38 million cubic meters, or $19 \%$, can be stored in reservoirs("Thailand Board of Investment (BOI),2009 ").

\subsubsection{Roads and Highways}

A good infrastructure is essential for the growth of trade, nationally and internationally alike. Thailand has a good road network of more than $250,000 \mathrm{kms}$, of which $51,466 \mathrm{kms}$ is national highways. All major cities in Thailand are accessible by land, with all-weather highways and intercity roads linking them to the road network covering the whole country, as well as the Asian Highway and the road networks of neighbouring countries over the border crossings(See, Thailand Country Conditions Climate for Investment \& Trade( Jan,2008). Therefore, the transportation of goods and raw material is very easy between different areas. This, in turn, 
encourages establishments of businesses in every part of the country and at the same time the products and services can reach all other parts easily.

\subsubsection{Railways}

Thailand has an extensive network of rail system spanning 4,070 km of railways that constitute a vital link in the transportation chain. Twenty-seven countries in an intergovernmental meeting here are preparing to link $80,000 \mathrm{~km}$ of railway lines to form a Trans-Asian Railway (TAR) network. At present, export and import of goods can be conveniently transported by train through the Thai-Malaysian border without further unloading.

The traffic is made via Sungai Kolok and Badang Besar Stations on the eastern and western borders of Malaysia respectively. Frequent shippers with a high volume of goods transported do enjoy train services through and from Singapore. In short, highway and railway systems provide exporters and importers with good facilities to make successful and promising businesses(State Railway of Thailand website 2009).

\subsubsection{Airports and Seaports}

Thailand has a coastline of 3,219 $\mathrm{km}$ with over 4,000 km of waterways, and has 122 ports, wharves, and jetties including eight deep-sea international ports, to facilitate the movement of all vessels engaged in the international trade. Ports include Bangkok, Laem Chabang, Pattani, Phuket, Sattahip, Si Racha, and Songkhla with very big capacity. It follows that the sea transportation in the country is very easy and convenient locally and internationally. Incidentally, Thailand also has 28 commercial airports, 5 of which are international airports with very big capacity (Thailand Country Conditions Climate for Investment \& Trade Jan,2008).

\subsubsection{Telephone and Mobile Services}

Thailand's telecommunications services are on par with the international standards, especially in urban areas such as Bangkok. There is an abundance of fixed lines for offices and residences. There are an increasing number of mobile phone subscribers and internet throughout Thailand and this number is sharply increasing over years. Thailand has competitive networks of fixed telephone lines 6.6 Mn (2007), mobile telephones 16.117 Mn (2007) (Investment Review: Foreign Investment climate, 2007), dial-up Internet and ADSL broadband which are getting more advanced over years and many new investors are establishing new projects. The Thailand Internet Service Provider Association stated that, at the end of 2007, there were 600,000 broadband subscribers, and it expected to rise to just under $1 \mathrm{Mn}$ by the end of 2008. Within 2009, the number is projected to reach to a high range between $5 \mathrm{Mn}$ and $10 \mathrm{Mn}$ subscribers(Thailand Telecommunications Report Q2 2009).

\subsection{Service Industry}

Like other countries in the south eastern Asia, the service industries have been one of the fast growing sectors in Thailand. Services are offered in transportation, construction, retailing/wholesale, finance, and tourism (Kasikorn Research Centre, 2006). For the companies belonging to this sector in Thailand, many of them were considered to be part of 
small and medium enterprises (SMEs).

As a matter of fact, the service-related employment accounted for more than two-thirds of the total SME employments. According to (Manasserian, 2005), the service sector accounted for $45 \%$ of the country GPD.

In addition, based on the SWOT analysis (strength-weakness-opportunity-threat), it appears that there is a clear urgency on improving the competitiveness in the service sector of the country. This relates to prepare service providers for globalization as well as their long-term ability to support manufacturing firms.

\subsubsection{Health, Beauty and Wellness}

This sector is crucial for the Thai economy, interestingly enough, foreign patients are becoming significant sources of income for Thailand's private and public hospitals because their purchasing power is considerably higher than the average domestic patients. On the other hand, Thailand's cost of living is much lower than in Japan, the U.S. and Europe, making the cost of medical care in Thailand much lower than what foreign patients have to pay in their own countries. This is one of the main reasons why private hospitals in Thailand are becoming more and more popular to foreigners seeking medical care overseas. According to figures released by the Private Hospital Association, Thailand, a total of 970,000 foreign patients sought medical diagnosis and treatment in private hospitals in Thailand during 2003, generating a total income of about Baht 19,000 million. By 2010 the total number of foreign patients is expected to reach the two-million mark and the total income generated will be about Baht 80,000 million. This bright forecast has prompted Thai private hospitals to adjust marketing and product strategies to meet the growth of medical care requirements as well as capitalize on the new opportunities on its relative competitive advantage.

\subsubsection{Tourism Industry}

The tourism sector is the king-pin of the Thai economy. The international tourism industry in Thailand has established an impressive record of growth over the last decades. Breathtaking scenery, local culture, historical sites, landmarks and architecture, hospitality, and politeness of the people remain strong points for Thailand's tourism. Accepted worldwide as the destination for best cuisine, best value destination, best beach to swim and most exciting outdoor market, Thailand is a gateway to Indochina: Vietnam, Lao, China and Cambodia.

Under the new slogan "Thailand Unforgettable", marketing activities will seek to accentuate Thailand's key strengths as an ideal tourist destination: sun, sand and sea; modernity and heritage; and shopping, dining and golfing, and warmth of friendliness.

Thailand's national development plans call for meeting the challenge of simultaneously attracting both large spending tourists as well as those who are willing to extend the length of their visits. Tourism is a major economic factor in the Kingdom of Thailand, contributing an estimated $6.7 \%$ to Thailand's GDP in 2007. Tourist numbers have grown from 336,000 foreign visitors and 54,000 R\&R soldiers in 1967(OUYYANONT, September 2001) to over 14 million international guests visiting Thailand in 2007. The average duration of their stay in 2007 was 
9.19 days, generating an estimated 547,782 million Thai baht (11 billion Euros)("Tourism Authority of Thailand (TAT) retrieved on 9/5/2009 from http://www2.tat.or.th/stat/web/static_index.php,"). In 2006, Thailand was the 18th most visited country in the World Tourism rankings ("UNWTO World Tourism Barometer (June 2007),")with 13.9 million visitors. Even though the global financial crisis and the political problems in Thailand were main reasons in the drop of tourist arrivals during 2008, it was expected that around $17 \mathrm{Mn}$ tourists would arrive during 2009(Thailand Tourist Report Q1 2009).

There is new but growing phenomenon called medical tourism. Nowadays, it is common that a patient travels from the United States to a high-quality hospital in New Delhi or Bangkok for heart surgery- the surgery might be performed by a doctor who got qualified in the US - with very less price comparing to that in The US. (Innovation Abroad, 2008).

The Spa industry in Thailand is fast growing and promising since many international tourist arrivals to Thailand intend to enjoy Thai physical treatments and Spa. The International Spa Association has reported that $63 \%$ of Americans tourists are likely to visit a spa while travelling. Some tourists arrivals decide to visit Thailand to improve their health through spa treatments as part of Thai therapies.

Spa services in Thailand are categorized into: day spa; hotel, resort spa; destination spa; medical spa, mineral spring spa; and spa cuisine. Visitors have an access to a wide choices of treatments and therapies including: hydrotherapy and supplementary massages, physical stretching and therapy such as body massage, facial massage, traditional Thai massage, yoga, medical nutritional control and beauty care(" 05 HEALTH AND WELLNESS. Travel Agent, 9/15/2008 Thailand Supplement,"). These new and growing kind of branded products attract tourists from all around the world and this creates many business opportunities for locals and international entrepreneurs in the country.

\subsubsection{Banking Industry and Finance}

Thailand is a major financial centre with an integrated banking networks (Thailand: Country Analysis Report - In-depth PESTLE Insights, 2009). It has a good banking network consists of many commercial banks local and foreigners, which are playing a significant role in the financial sector of the economy. This facilitates the process for investors to financing their projects. Further, the government is developing different plans and considering various reforms agendas, including establishing an integrated financial regulatory agency that would free up the Bank of Thailand to focus on monetary policy(Thailand: Country Analysis Report - In-depth PESTLE Insights, 2009).

In addition, the Thai government is attempting to strengthen the financial sector through the consolidation of commercial, state-owned, and foreign-owned institutions. It may be mentioned that the government's Financial Sector Reform Master Plan, which was first introduced in early 2004, provides tax breaks to financial institutions that engage in mergers and acquisitions. Thai reform programs have been deemed successful by outside experts. As of 2007, there were three state-owned commercial banks and five state-owned specialized banks, 
15 Thai commercial banks, and 17 foreign banks in Thailand (Thailand Country Profile, July 2006).

\subsection{Foreign Economic Relations}

Thailand participates actively in regional and international organizations. Thailand is moreover keen on expanding its international trade channels through free-trade agreements and multilateral cooperation within such organizations as the Asian Development Bank (ADB), Asia-Pacific Economic Cooperation, Association of Southeast Asian Nations (ASEAN), and World Trade Organization (WTO)(Thailand: Country Analysis Report - In-depth PESTLE Insights,2009).

Thai government has developed increasingly close eco-political ties with other ASEAN members-Indonesia, Malaysia, the Philippines, Singapore, Brunei, Laos, Cambodia, Burma, and Vietnam. Regional cooperation of the country is progressing well in economic, trade, banking, political, and cultural matters. These regional relationships have served for the stability of the peace in the region and enhancement of the economic integrity(Thailand Country Conditions Climate for Investment \& TradeJan,2008).

Furthermore, Thailand developed good longitude relationships with Japan and the United States which are the top two trading partners and sources of direct investment of the nation. Thailand has granted the United States preferential treatment for investment under the Thai-U.S. Treaty of Amity and Economic Relations of 1966. Despite close economic ties between Thailand and the United States, however, there has been unending disputes over agricultural trade, intellectual property rights, and customs procedures.

In July 2005, Thailand had concluded bilateral free-trade agreements with key trading partners, such as Australia, New Zealand, China, India, and Bahrain. China is gaining its importance as a trading partner of the country in spite being a hard competitor for foreign direct investment and export markets, particularly in the areas of agriculture, computer hardware, and textiles (Thailand Country Profile, July 2007).

As developing countries need to define their measurements of Total Quality Management (TQM) principles to enhance their global competitiveness, the Thai manufacturing and service sectors are keen to adopt the international quality standards such as ISO 9000, ISO 14000, and others to increase their demands and improve their performance. TQM processes would enable Thailand's products and services to penetrate to the global markets confidentially and kept continuously improving and becoming more innovative(Das, Paul, Swierczek \& Laosirihongthong, 2006).

\section{Thailand Competitive Disadvantages}

The country's policy-makers should work hard to surmount some of the hard corners of its competitive disadvantages, such as

\subsection{Political Instability}

Thailand has been suffering from the instability of the political system, this in turn; may 
adversely affect the inflow of FDI into Thailand and discourages the flow of international tourists to the country. This coupled with the negative effect of the global financial crises which caused the FDI to scale down due to the high level of uncertainties. The ever changing political system and the unstable government can cause political risks which, in turn; will adversely affect the level of foreign and domestic investment in the country.

In today's world there are many features that are considered to be significantly important for investors to establish their business at any environment, one of these is the degree of the political stability of the country in which they are planning to enter for business. This is the more significant factor in determining the flow of FDI into any country(Lambsdorff, November 1999).

Determinants of political risks such as change of regime, government intervention in the economic situations, property rights legislation, and red tape may adversely affect the decision process of foreign investments (Frey \& Schneider, 1979). However, the international investors and the international organizations give high importance for their FDI decision process on how good is the governance index of each country such as: fighting corruption; transparency of the administration processes; and violence free environment("World Bank, 2006).

\subsection{Lack of Technical Training}

One of the disadvantages that can be identified in Thailand is the lack of scientifically and technologically skilled human resources or well- structured vocational training programs. Thailand, in fact, is in severe and increasing need for technically skilled workers. In its ninth National Social and Economic Development Plan (2002-2006) the government Thailand had stressed in the development of Human Resources in order to meet the development processes needs as well as the increasing economic challenges(Hawley \& Paek, 2005).

The slow progress of human resource development can be an obstacle to the process of the economy transition towards knowledge- Based economy and to achieve a sustainable competitiveness. The Asian Development Bank's (ADB) country operational strategy (COS) in 1993 rightly concluded that Thailand economy was in transition, and there are structural balances caused by the economic rapid growth will cause difficulties in the economic performance in the long run.

The main constraints were the weaknesses in human resources, technical training, and technology to support and meet the needs of fast-paced development processes. One of COS studies in 1999, prepared after the Asian economic crisis, emphasized that the Thai economy needed to move away from labor-intensive production because Thailand was no longer competitive. The COS insisted on that the human resources should be reoriented towards science and technology especially in higher education institutions, as a primary requirement for Thai continued growth and sustainable development (Asian Development Bank Completion report, 2006).

\subsection{The In competitiveness of Thai Educational System}

The Thai education system and training plans, particularly the higher education, is not 
qualified to lead the country's development. Although a shortage of skilled labor is emerging, the future growth has to be led by the industry sector with higher levels of technology. Technology and job-oriented educational programs are essential in the country, however, the enrollments in higher education had been mainly skewed towards the humanities at the expense of Science and technology education. For example, in 2002only 6\% of the enrolled students in the higher education system were in engineering, with similar number enrolled in mathematics and computer science, while $20 \%$ enrolled in business administration programs (Thailand Country Profile, 2007).Secondly, English as a medium of education is least emphasized in the country. This needs to be taken care of by the policy-makers to enhance the competitive advantage of the country.

\subsection{Corruption}

One of the major issues of Thailand is that, the country has been suffering from high levels of corruption. This spread level of corruption in the country's political and bureaucratic machinery has been a serious problem, and can adversely affect the investment flows in the country. As a matter of fact, Transparency International's corruption perceptions index for 2008, which measures the perceived levels of public sector corruption, ranked Thailand 80th out of 179 countries ranked under this category (Thailand: Country Analysis Report - In-depth PESTLE Insights).

\section{Summing Up}

This paper endeavoured to examine the attributes of Thailand's national competitiveness. Thailand has a potential to achieve a competitive edge not only because its natural resources, but also because of Human efforts exerted to organize, utilize, and improve the available competitive activities. However, The Thai financial and economic sectors were hit by the financial crisis 1997 and jolted further by the financial global crises 2008 that scaled down the FDI inflows to the country and shrank its overall economic growth performance.

Indeed, a agricultural sector is the king-pin of Thai competitiveness, moreover, the quality of the Thai soil provides a good environment ground for those who want to invest in agriculture and Agriculture-based industry. Secondly, tourism in Thailand is very active and promising sector. The availability and low cost labor force may be one of the main factors which attract the inflows of FDI to the country.

On the other hand, the lack of skilled labor forces, uncompetitive educational system, and most importantly the instability of political system are on the minus side of the competitive edge of the country. Therefore, it is very important that policy makers of the country should maintain an overall favourable business and investment climate (including for FDI) and refrain from protectionist tendencies.

\section{References}

Asian Development Bank, (2006). Competition Report September,

Bangkok Companies website. (2009). Retrieved May 10, 2009, from http://www.bangkokcompanies.com/thailandoverview.htm. 
Das, A., Paul, H., Swierczek, F. W., \& Laosirihongthong, T. (2006). A Measurement Instrument For TQM Implementation in the Thai Manufacturing Industry. International Journal of Innovation and Technology Management 3(4), 361-377. http://dx.doi.org/10.1142/S0219877006000879

Euromonitor International Statistics website(2009). Retrieved April 26, 2009, from http://www.portal.euromonitor.com.eserv.uum.edu.my/passport/Statistics.aspx

Frey, B., \& Schneider, F. (1979). An econometric model with an endogenous government sector. Puplic choice, 34, 29-43. http://dx.doi.org/10.1007/BF00125750

Hashim, F., \& Jedin, M. H. (2007). International Business: An Asian Perspective. Shah Alam: Oxford FAJAR Sdn. Bhd.

Hawley, J. D., \& Paek, J. (2005). Developing human resources for the technical workforce: a comparative study of Korea and Thailand. International Journal of Training and Development, 9(1), 79-94. http://dx.doi.org/10.1111/j.1360-3736.2005.00223.x

Hodgetts, R. M. (1993), Porter's Diamond Framework in a Mexican Context, Management International Review, 33(2), 41-54.

Innovation Abroad. (2008). Health Affairs, 27(5).

Intarakumnerd, P., \& Panthawi, P. (Eds.). (2003). Science and Technology Development Toward a Knowledge-based Economy.

Investment Review: Foreign Investment climate. (2007). Thailand Review.

Jasimuddin, S. M. (2001) Analyzing the competitive advantages of Saudi Arabia with porter's model. Journal of Business \& Industrial Marketing, 16(1), 59-68. http://dx.doi.org/10.1108/08858620110365007

Jong, J. P. J. d., \& Hartog, D. N. D. (2007). How leaders influence employees' innovative behaviour. European Journal of Innovation, 10(1), 41-64. http://dx.doi.org/10.1108/14601060710720546

Kao et al., (2008). Measuring the national competitiveness of the Southeast countries. European Journal of operation research, 187 ,613-628

Kasikorn Research Centre (2006), Thai service sector: adjustment and liberalization. Retrieved May 23, 2009, from www.kasikornresearch.com/kr/eng/econ_analysis.jsp

Lambsdorff, J. (November 1999). Corruption in empirical research-A review. Quarterly Journal of Economic, 110(3), 681-712.

Lukuthai, S. (2007). The importance of the food industry to the Thai Economy:An Input-Output perspective, ASEAN Economic Bulletin; 24(2)

Manasserian, T. (2005), New realities in global markets and Thailand's economy today. Retrieved May 20, 2009, from http://webh01.ua.ac.be/cas/PDF/CAS48.pdf . 


\section{Macrothink}

Business and Economic Research ISSN 2162-4860 2014, Vol. 4, No. 1

Meyer, K., \& Estrin, S. (October 4, 2004). Investment Strategies in Emerging Markets. Edward Elgar Publishing.

Ouyyanont, P. (September 2001). The Vietnam War and Tourism in Bangkok's Development, 1960-70. Southeast Asian Studies, 39(2), 157-187.

Phusavat, K., \& Kanchana, R. (2007),Industrial Management \& Data Systems Vol. 108 No. 1, 2008 pp. 5-21

Porter,M. (1990), The Competitive Advantage of Nations, The free Press, New York,NY.

State Railway of Thailand website (2009). Retrieved May 10, 2009, from http:www.railway.co.th/English/pro15_masterplan.asp

Thai Board of Investment website. (2009). http://www.tceb.or.th

Thailand Board of Investment (BOI) website accessed on 10/5/2009 from http://www.boi.go.th/english/how/water_supply.asp.

Thailand Board of Investment (BOI) website. accessed on 10/5/2009 from http://www.boi.go.th/english/how/electricity.asp.

Thailand Country Conditions Climate for Investment \& Trade( Jan,2008) Political Risk Services Retreived May7, 2009, from http:///web.ebscohost.com

Thailand Country Profile (2007). The Economist Intelleigence Unit Limited. Retrieved May 7, 2009, from www.eiu.com.

Thailand Country Profile (2008). The Economist Intelleigence Unit Limited. Retrieved May 9, 2009, from www.eiu.com.

Thailand Country Profile. (2007). Library of Congress-Federal Research Division. Retrieved May 1, 2009, from http://lcweb2.loc.gov

Thailand Industry Forecast December 2005. The Economist Intelligence Unit Limited Retrieved on 8/5/2009 from www.eiu.com.

Thailand Infrastructure Report Q2 2009. BUSINESS MONITOR INTERNATIONAL LTD Retrieved on 8/5/2009 from http://www.businessmonitor.com.

Thailand National Statistics Office website (2009). Retrieved April 26, 2009, from http://web.nso.go.th/index.htm

Thailand Telecommunications Report Q2 2009. BUSINESS MONITOR INTERNATIONAL LTD.

Thailand Tourist Report Q1 2009. Business Monitor International Ltd.

Thailand: Country Analysis Report - In-depth PESTLE Insights January.(2009). Retrieved May 20, 2009, from http://web.ebscohost.com

Thailand: Country Analysis Report - In-depth PESTLE Insights (2009). Datamonitor. 


\section{Macrothink}

Business and Economic Research

ISSN 2162-4860 2014, Vol. 4, No. 1

The Free Encyclopedia (2009). http://en.wikipedia.org/wiki/Tourism_in_Thailand

Tourism Authority of Thailand (TAT) retreived on 9/5/2009 from http://www2.tat.or.th/stat/web/static_index.php

UNWTO World Tourism Barometer (June 2007). www.unwto.org, 5(2).

Winley, G., Arjpru, C., \& Wongwuttiwat, J. (2007). The Electronic Journal on Information Systems in Developing Countries [Electronic Version], 31, 1-28.

\section{Copyright Disclaimer}

Copyright reserved by the author(s).

This article is an open-access article distributed under the terms and conditions of the Creative Commons Attribution license (http://creativecommons.org/licenses/by/3.0/). 